\title{
AGES OF THE GOVERNORS OF IOWA ON ASSUMING THEIR DUTIES
}

The question of the age of some one of the governors of our state having frequently arisen, or the question as to who was the youngest, or who among them was the oldest at time of service, we have tabulated the following:

\section{TERRITORIAL GOVERNORS}

Robert Lucas ${ }^{1}$

John Chambers

James .Clarke

Ansei Briggs

Stephen Hempstead James W. Grimes

Ralph P. Lowe

Samuel J. Kirkwood

William M. Stone

Samuel Merrill

Cyrus C. Carpenter

Samuel J. Kirkwood

Joshua G. Newbold

John H. Gear

Buren R. Sherman

William Larrabee

Horace Boies

Frank D. Jackson

Francis M. Drake

Leslie M. Shaw

Albert B. Cummins

Warren Garst

Beryl F. Carroll

George W. Clarke

William L. Harding

Nathan E. Kendall

John Hammill

Date of Taking Office Age at time of Taking Office

Aug. 15, 1838

57 yrs. 4 mos. 14 days

May 12, 1841

60 " 7 " 6 "

Nov. 18,1845

33 " 4 " 13 "

\section{STATE GOVERNORS}

\begin{tabular}{|c|c|c|c|c|c|c|}
\hline Dec. 3,1846 & 40 & & \multicolumn{2}{|c|}{$10 \mathrm{mos}}$. & \multicolumn{2}{|c|}{0 day } \\
\hline Dec. 4,1850 & 38 & 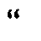 & 2 & & 3 & \\
\hline Dec. 9,1854 & 38 & “ & 1 & “ & 19 & “ \\
\hline Jan. 13,1858 & 52 & “ & 1 & “ & 16 & ، \\
\hline Jan. 11,1860 & 47 & “ & 0 & “ & 21 & ، \\
\hline an. 14,1864 & 36 & " & 3 & “ & 0 & “ \\
\hline Tan. 16,1868 & 45 & " & 5 & " & 9 & “ \\
\hline Jan. 11,1872 & 44 & “ & 1 & “ & 17 & . \\
\hline Jan. 13,1876 & 63 & “ & 0 & “ & 23 & ' \\
\hline eb. $\quad 1,1877$ & 46 & “ & 8 & “ & 19 & “ \\
\hline an. 17,1878 & 52 & $“$ & 9 & “ & 10 & 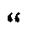 \\
\hline an. 12,1882 & 45 & $“$ & 7 & “ & 14 & “ \\
\hline an. 14,1886 & 53 & “ & 11 & $"$ & 24 & “ \\
\hline eb. 27,1890 & 62 & " & 2 & “ & 27 & “ \\
\hline an. 11,1894 & 39 & “ & 11 & “ & 15 & “ \\
\hline an. 16,1896 & 65 & “ & 0 & “ & 16 & 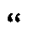 \\
\hline Ian. 13,1898 & 49 & $"$ & 2 & “ & 11 & “ \\
\hline Jan. 16,1902 & 51 & $"$ & 11 & “ & 1 & “ \\
\hline Nov. 24,1908 & 57 & “ & 11 & “ & 20 & “ \\
\hline Jan. 14, 1909 & 48 & " & 9 & " & 29 & “ \\
\hline Jan. 16, 1913 & 60 & " & 2 & “ & 18 & “ \\
\hline Jan. 11, 1917 & 39 & " & 3 & “ & 8 & “ \\
\hline Jan. 13,1921 & 52 & " & 9 & " & 26 & “ \\
\hline Jan. 15,1925 & 49 & “ & 3 & “ & 1 & \\
\hline
\end{tabular}

1We have taken the date of "assuming their duties" to be, with Lucas and Chambers, when they arrived in the territory; with James Clarke, when he was appointed, is he was already residing in the territory; and with the state governors, when they were inaugurated. 
Copyright of Annals of Iowa is the property of State of Iowa, by \& through the State Historical Society of Iowa and its content may not be copied or emailed to multiple sites or posted to a listserv without the copyright holder's express written permission. However, users may print, download, or email articles for individual use. 